\title{
Radikaali psykologinen turvallisuus tilapäisorganisaation luovan ja tuloksellisen toiminnan mahdollistajana
}

\author{
Virva Salmivaara, Frank Martela \& Jukka-Pekka Heikkilä
}

\begin{abstract}
Psychological safety in temporary organisations

We explore how psychological safety-a team's shared experience that it is safe to take inter-personal risks-is possible in temporary self-managing organisations. Our findings present teamwork practices used by a highly diverse group that constructed a complex art installation for the Burning Man festival. Based on a questionnaire and a qualitative analysis of 20 interviews, we suggest that the team experienced radically high psychological safety because it defined the project's concept through co-creation, gave participants complete freedom to choose their roles, and collectively challenged participants.
\end{abstract}

Keywords: Psychological safety, temporary organisation, swift trust, Burning Man

\section{JOHDANTO}

Asiantuntija- ja tiimityön lisääntyminen modernissa työelämässä on johtanut siihen, että ihmisten työtä koskevat tunteet ja keskinäinen dynamiikka ovat yhä keskeisemmässä roolissa tulosten aikaansaamisen kannalta (Barsade \& Gibson 2007). Yhdeksi keskeiseksi luovuutta ja tuloksellisuutta ennustavaksi tekijäksi on noussut $p s y k o$ loginen turvallisuus, jota on empiirisesti tutkittu 1990-luvulta lähtien (ks. Edmondson \& Lei 2014). Psykologinen turvallisuus määritellään "tiimin jäsenten jakamaksi uskomukseksi siitä, että tiimissä on turvallista ottaa ihmistenvälisiä riskejä" (Edmondson 1999, 350). Tällaisessa tiimissä jäsenet uskaltavat kertoa orastavista ideoistaan ja keskustella avoimesti ongelmista ja ratkaisuista, mikä mahdollistaa yhdessä oppimisen.

Tuore meta-analyysi 136:sta tutkimuksesta osoittaa, että psykologisella turvallisuudella on selkeä yhteys sekä tiimin jäsenten työn imuun ja tyytyväisyyteen että tiimin oppimiskykyyn, informaation jakamiseen, luovuuteen ja tuloksellisuuteen (Frazier ym. 2017). Tutkijoiden sekä yritysjohdon keskuudessa on yhä vahvemmin ymmärretty psykologisen turvallisuuden keskeisyys tiimityön tuloksellisuuden takaajana (Duhigg 2016). Valtaosa psykologista turvallisuutta koskevasta tutkimuksesta on kuitenkin ollut määrällistä ja keskittynyt lopulta pieneen joukkoon psykologista turvallisuutta ennustavia tekijöitä (Edmondson \& Lei 2014; Frazier ym. 2017). Edmondson ja Lei $(2014,39)$ huomauttavat kentän kaipaavan enemmän tutkimuksia, jotka tarkastelisivat ilmiötä laadullisesti, jotta psykologisen turvallisuuden kokemuksista saataisiin syvempi ymmärrys.

Erityisen haasteen psykologisen turvallisuuden syntymiselle tuo nykypäivän työelämä, jossa lyhyet, määräaikaiset työsuhteet, vaihtuvat projektit ja irtisanomiset ovat yleisiä. Ihmiset eivät välttämättä työskentele samassa organisaatiossa pitkään, eivätkä ehdi tutustua toisiinsa sillä tavoin, että jäsenten välille syntyisi syvä luottamus ja kokemus riskinoton mahdollisuudesta. Goodman \& Goodman (1976) määrittelevät tilapäisen organisaation väliaikaiseksi järjestelmäksi, jossa ryhmän jäsenet eivät ole aiemmin työskennelleet yhdessä eivätkä he odota näin tapahtuvan tulevaisuudessa. Tilapäinen organisaatio voi olla esimerkiksi projekti, jolla on aloitus- ja lopetuspäivämäärä. Bakker (2010) esittää, että menestyksekkäissä tilapäisissä organisaa- 
tioissa rakennettaan "ketterää luottamusta", joka syntyy nopeasti eikä edellytä pitkää ajanjaksoa, jolla vaalitaan ryhmän yhteistyötä ja luodaan yhteistä kokemuspohjaa. Ketterän luottamuksen vallitessa käyttäydytään siten kuin luottamus olisi läsnä, vaikka organisaation historiallinen tausta osoittaa, että ihmiset eivät tunne toisiaan $\mathrm{ja} /$ tai organisaatio on juuri aloittanut toimintansa (Meyerson ym. 1996). Aikaisempi tutkimustieto (esim. Frazier ym. 2017) viittaa siihen, että ketterä luottamus syntyy tilapäisorganisaatioissa, joissa on selkeät, yhteiset pelisäännöt sekä johtamistapa, joka tukee tiimin jäsenten välistä dialogia ja kanssakäymistä. Tutkimuksen valossa tiedämme kuitenkin vielä vähän millä tavoin ketterä luottamus ja psykologinen turvallisuus syntyvät tilapäisorganisaatioissa (Jones \& Lichtenstein 2008; Meyerson ym. 1996; Saunders \& Ahuja 2006). Erityisen kiinnostavaa on tarkastella, miten psykologinen turvallisuus näyttäytyy ja muodostuu organisaatiomalleissa, joissa ihmiset pääsevät toimimaan vahvan itseohjautuvasti ilman ennalta määriteltyjä sääntöjä, hierarkiaa tai vahvaa ohjausta (Lee \& Edmondson 2017; Martela 2019; Martela \& Kostamo 2017).

Tällä tutkimuksella pyrimme täyttämään puutteellista tutkimuskenttää tarjoamalla laadullista ymmärrystä psykologisen turvallisuuden ilmenemisestä ja sen mahdollistajista tilapäisessä organisaatiossa, erityisesti ketterän luottamuksen näkökulmasta. Tutkimukseen kohteena on tilapäinen, eri alojen osaajia yhdistänyt suomalainen Space on Fire -projekti, jonka jäsenet rakensivat itseohjautuvasti ja vapaaehtoisvoimin erittäin haastavan, puuarkkitehtuuria sekä avaruusteknologiaa yhdistäneen taideinstallaation Nevadan autiomaassa järjestettävässä Burning Man -tapahtumassa. Pyrimme haastattelujen sekä kyselyn pohjalta saamaan vastauksen kahteen kysymykseen:

- Minkälaista oli psykologinen turvallisuus tilapäisorganisaation mallia käyttäneessä Space on Fire -projektissa?

- Mitkä tekijät mahdollistivat psykologisen turvallisuuden muodostumisen kyseisessä projektissa?

\section{PSYKOLOGINEN TURVALLISUUS, TILAPÄISET ORGANISAATIOT SEKÄ KETTERÄ LUOTTAMUS}

\section{Psykologinen turvallisuus}

Psykologinen turvallisuus (psychological safety) on viimeisen kahdenkymmenen vuoden aikana noussut merkittäväksi organisaatiotutkimuksen kohteeksi. Se määritellään "tiimin jäsenten jakamaksi uskomukseksi siitä, että tiimissä on turvallista ottaa ihmistenvälisiä riskejä" (Edmondson 1999, 350). Psykologinen turvallisuus liittyy ryhmän jäsenten yhtenäiseen kokemukseen siitä, että organisaatiossa ei ole ihmisten väliseen vuorovaikutukseen liittyviä uhkia (Edmondsonin $1999,2004)$, ja se vahvistaa ihmisten halua osallistua yhteiseen keskusteluun ja tekemiseen (Kahn 1990). Psykologinen turvallisuus mahdollistaa työntekijöille kyvyn "tuntea turvaa, kasvaa, oppia sekä osallistua" (Edmondson \& Lei 2014, 23), ja vahvistaa näin ryhmän resilienssiä eli kykyä reagoida ja selvitä muutoksista.

Luottamus (trust), jota myös on tutkittu organisaatiotasolla (esim. Carmeli \& Gittell 2009) on yksi psykologisen turvallisuuden osatekijä, mutta psykologinen turvallisuus on ilmiönä sitä laajempi. Toisin kuin luottamus, psykologinen turvallisuus sisältää myös ryhmässä vallitsevan kunnioituksen ja välittämisen ilmapiirin, jotka yhdessä synnyttävät uskalluksen ottaa ihmistenvälisiä riskejä (Edmondson 1999). Lisäksi psykologinen turvallisuus liittyy passiivisempaa luottamusta suoremmin henkilöiden ryhmässä kokemiin toimintamahdollisuuksiin. Psykologista turvallisuutta syntyy, kun ryhmän jäsenet huomaavat, että kipukohtien käsittely ei johda ryhmän hajautumiseen, vaan ryhmä käsittelee tietoa oppiakseen virheistä (Edmondson 1999; Frazier ym. 2017).

Aiempi tutkimus on myös todennut, että psykologisen turvallisuuden vallitessa työntekijät tuntevat olevansa merkityksellisiä ja osallistuvat mielellään organisaation eri rooleihin (Edmondson \& Lei 2014; Kahn 1990). Psykologinen turvallisuus kytkeytyy näin psykologisen voimaantumisen (psychological empowerment) käsitteeseen, joka viittaa yksilön tunnetilaan, jossa henkilö kokee olevansa merkityksellinen, kyvykäs ja vaikuttava ja että hänellä on itsemääräämisoikeus (Spreitzer 1995). Psykologinen 
turvallisuus liittyy myös työhön sitoutumiseen ja työn imuun (work engagement), joka tarkoittaa, että organisaation jäsen investoi resurssejaan sekä energiaansa työtehtäviinsä ja on innoissaan työstään (Christian ym. 2011; Hakanen ym. 2008; Kahn 1990).

\section{Tilapäiset organisaatiot ja ketterä luottamus}

Organisaatioiden tilapäiseen luonteeseen on kiinnitetty huomiota jo pitkään. 1960-luvun puolivälissä Bennis $(1965,34)$ julisti, että "organisaatiot tulevat olemaan jatkuvasti nopean muutoksen alla olevia tilapäisiä järjestelmiä”. Bakker (2010) on määritellyt tilapäisen organisaation "ryhmäksi organisatorisia toimijoita, jotka toimivat yhdessä rajatun ajan". Laaja määritelmä koskee eri aloja kuten teatterituotantoja, ensiaputiimejä, rakennusprojekteja sekä yleisesti luovan alan organisaatioita. Tilapäisissä organisaatioissa toisiinsa sidoksissa olevat toimijat ovat keskenään hyväksyneet toimia tiettyä päämäärä kohden, tietäen että yhteistyö loppuu sovitun mukaisesti. Tämä "institutionaalinen lopetus" (Lundin \& Söderholm 1995, 445) erottaa tilapäisen organisoitumisen yleisistä organisaatioteorioista, jotka näkevät organisaation kontekstin jatkuvuuden avoimena.

Tilapäisorganisaatioissa työryhmällä ei ole aikaa kehittää henkilösuhteita samalla tavoin kuin perinteisissä organisaatioissa. Meyerson kollegoineen (1996) ehdottaa, että tällaisissa organisaatioissa kriittinen menestystekijä on ns. ketterä luottamus (swift trust), joka mahdollistaa erilaisilla tieto- ja taitopääomista muodostuvan ryhmän yhteistoiminnan. Organisaation jäsenten kokema haavoittuvuus, epävarmuus sekä riskit ovat ratkaistavissa ketterän luottamuksen avulla (Meyerson ym. 1996; Saunders \& Ahuja 2006).

Näkemykset tilapäisorganisaation ketterän luottamuksen ja yhteistoiminnan mahdollistajista jakautuvat kirjallisuudessa selkeästi kolmeen keskeiseen näkemykseen: normipohjaisiin, roolipohjaisiin ja suhdepohjaisiin. Normipohjaisia mahdollistajia korostavan näkemyksen mukaan ketterä luottamus edellyttää kontekstia, jossa on selkeät rajat ja säännöt (Grabher 2002). Tilapäinen organisointi on sidottu institutionaalisiin raameihin, jotka ohjaavat kuinka tietyn alan osaajat voivat siirtää tietoaan uusille alueille.

Roolipohjaisia mahdollistajia painottava näkemys esittää, että ketterää luottamusta voidaan synnyttää tilapäisorganisaatioissa, joissa työnjako on tarkasti strukturoitua (Bechky 2006). Informaation käsittely ja vuorovaikutus on järjestetty siten, että jäsenet voivat luottaa toisiinsa nopeasti (Meyerson ym. 1996, Saunders \& Ahuja 2006), ja tämän rakenteen myötä on mahdollista, että "nyanssit neuvotellaan hetkessä" (Bechky 2006).

Suhdepohjaisia mahdollistajia keskeisenä pitävä näkemys esittää, että on keskeistä nähdä kuinka sosiaaliset ja organisatoriset rakenteet elävät ajassa rinnakkain (Jones \& Lichtenstein 2008). Ajatuksena on, että ketterä luottamus on seurausta ryhmän jäsenten aiemmin luomista suhteista, jotka vähentävät epävarmuutta sekä lisäävät kollektiivista kokemusta yhteisestä päämäärästä. Jaettu ymmärrys "selventää sisällön, roolit sekä roolien käytöksen, joka on tarkoitettu tehokkaaseen koordinaatioon" (Jones \& Lichtenstein 2008, 249).

\section{Johtamisen rooli tilapäisissä itseorganisoituvissa ryhmissä}

Johtamisella on keskeinen merkitys ryhmän dynamiikan kehittämisessä ja ketterän luottamuksen - ja sitä kautta psykologisen turvallisuuden - luomisessa. Edmondsonin (1999) mukaan jaettu tehokkuuden kokemus tukee tiimin psykologista turvallisuutta. Kun ryhmä kokee olevansa tehokas, sen jäsenet uskovat tiimin kykyyn ja potentiaalin, ja uskaltavat näin ollen ottaa enemmän riskejä. Tätä voidaan tukea johtamisella, joka tarjoaa ryhmälle suunnan ja tavoitteet, palkitsee onnistumisista ja vähentää epätietoisuutta panostamalla tiedonkulkuun ja informaation läpinäkyvyyteen (Wageman 1997). Ryhmänjohtajan esimerkki ja toimintatapa on tärkeä etenkin ryhmän jäsenten reflektoidessa toistensa käytöstä (Edmondson 1999).

Usein tilapäinen organisaatio on kuitenkin itseorganisoituva ryhmä, jossa synnytetään spontaania järjestystä ilman keskitettyä tai ulkoista ohjausta ja kontrollia (Jalonen ym. 2013). Itseorganisoitumisen perusta on toimijoiden vuorovaikutuksessa, jota voidaan kuvata epälineaariseksi ketjuksi, jossa vuorottelevat kaaos sekä 
tasapaino. Tässä ketjussa itseorganisoituvan organisaation jäsenet oppivat ja saavat lisää informaatiota toisiltaan, mistä seuraa aina jonkinasteinen tasapainottomuus. Jäsenten saatua uuden informaation käsiteltyä, organisaatio järjestäytyy uudelleen (Ståhle 2004). Itseohjautuvissa tiimeissä johtaminen on usein vahvasti jaettua, mikä viittaa siihen, että jokaisen osallistujan rooli on keskeinen psykologisen turvallisuuden luomisessa (Lee \& Edmondson 2017; Martela \& Kostamo 2017).

\section{TUTKIMUKSEN KOHDE, TUTKIMUS- MENETELMÄT SEKÄ TUTKIMUSAINEISTO}

\section{Tutkimuksen kohde: Space on Fire -projekti}

Tutkimuksen kontekstina on Burning Man -tapahtuma, joka on maailman suurin ulkona ja vapaaehtoisvoimin toteutettava innovaatiotapahtuma. Vuosittain rakennettavaan, väliaikaiseen Black Rock City -kaupunkiin Nevadan aavikolle muuttaa viikoksi 75000 asukasta. Tapahtuman kantavia teemoja ovat luovuus, taide sekä yhdessä tekeminen. Tapahtuman kävijät tuottavat tapahtuman sisällön paikallisissa yhteisöissä, ja toteuttavat yhdessä taidetta tai kaupungin infrastruktuuria tukevia projekteja (Chen 2009). Tapahtumasta on tullut suosittu etenkin Piilaakson yrittäjien keskuudessa ja yritykset osallistu- vat tapahtumaan, mutta eivät saa käyttää sitä markkinoinnissaan (Turner 2009).

Tutkimuksemme kohteena on suomalaisyhteisön toteuttama, itseohjautuva vapaaehtoisprojekti Space on Fire (https://spaceonfire.com), jossa tehtäväksi muotoutui puuarkkitehtuuria sekä avaruusteknologiaa yhdistävän installaation rakentaminen Burning Man -tapahtumaan (kuva 1). Projektin tiimi koostui noin sadan vapaaehtoisen joukosta, jossa oli mukana eri alojen yrittäjiä, tutkijoita, asiantuntijoita ja opiskelijoita. Space on Fire -projektiyhdistivapaaehtoistoiminnan merkeissä yrityksiä (Reaktor Space Labs ja Lunden Architecture), tiedeinstituutioita (Aaltoyliopisto, Heureka sekä CERN) ja säätiöitä (Suomen Kulttuurirahasto, Walter Alhstromin säätiö), ja se oli osana Suomi 100 -juhlaohjelmaa. Yhdysvaltoihin matkanneessa 50 henkilön projektiryhmässä oli mm. arkkitehteja, insinöörejä, kosmetologi, diplomaatti, taikuri, pelisuunnittelija sekä kirjanpitäjä, muttei juurikaan ammattilaisia, joilla olisi ollut rakennuskokemusta. Tästä huolimatta projekti onnistui rakennustavoitteissaan (Aalto-yliopisto 2017). Projektiryhmä pyrki toteuttamaan itseohjautuvaa organisaatiomallia, jossa pienemmät osatiimit saivat toimia konsensushakuisesti itse parhaaksi katsomallaan tavalla. Organisaation aikajänne oli lyhyt: Projekti käynnistyi ryhmän ensimmäisessä tapaamisessa lokakuussa 2016, ja sen

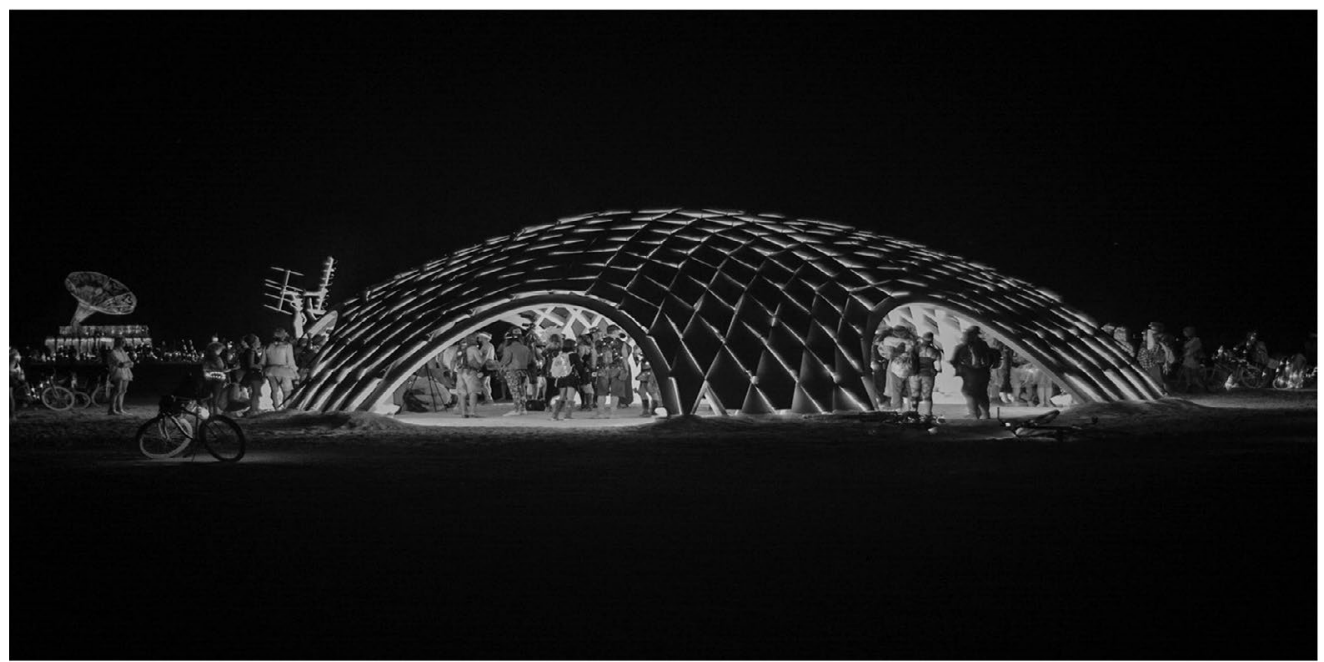

Kuva 1. Cosmic Egg. Space on Fire -projektiryhmän installaatio, Burning Man 2017. 


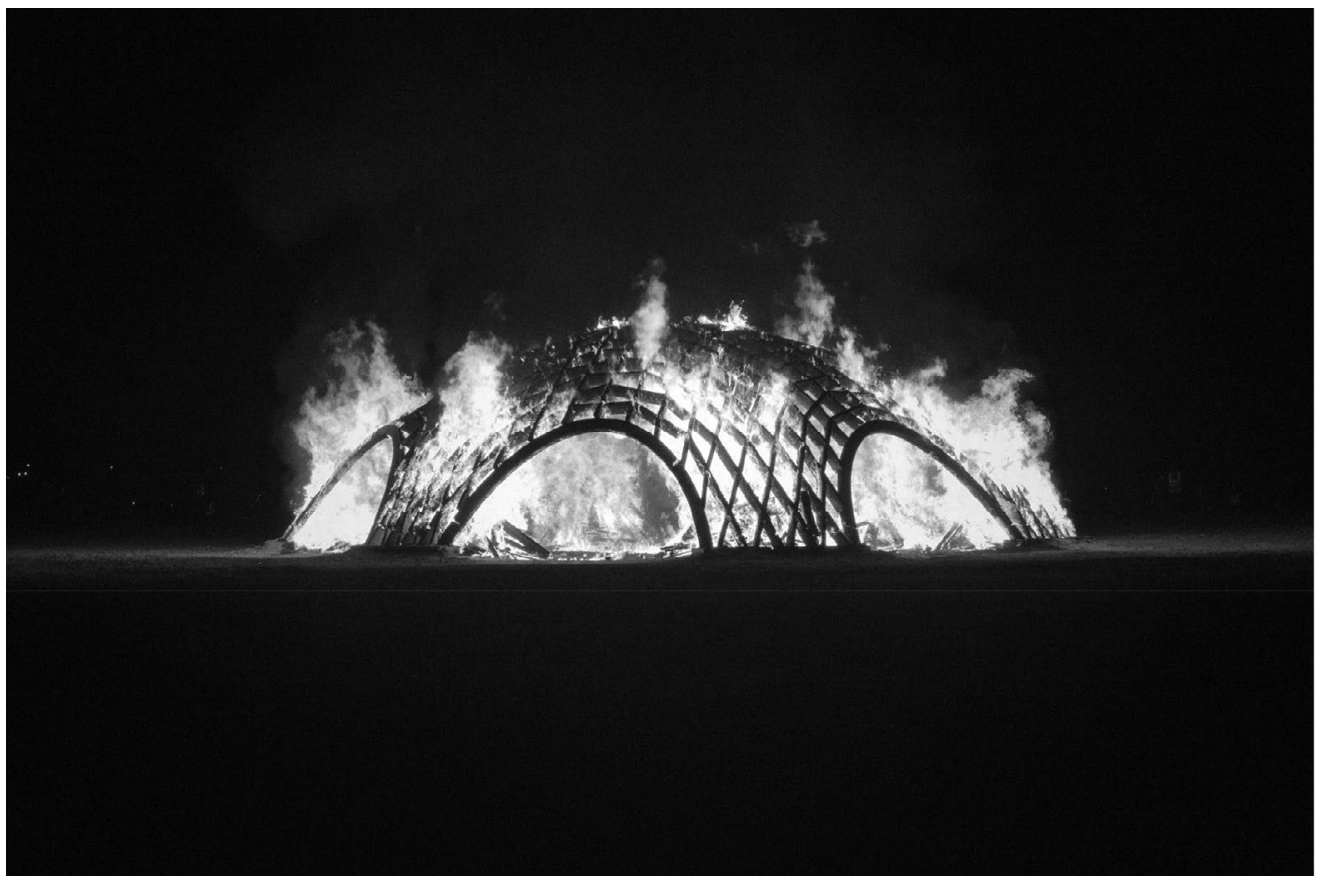

Kuva 2. Space on Fire -projektin institutionaalinen lopetus eli Cosmic Egg -installaation polttaminen.

"institutionaalinen lopetus" (Lundin \& Söderholm 1995) tapahtui, kun projektiryhmän rakentama Cosmic Egg -installaatio poltettiin Nevadan autiomaassa elokuussa 2017 (kuva 2). Installaatioiden polttaminen on keskeinen osa Burning Man -konseptia. Projekti jakautui lähinnä Suomessa tapahtuneeseen valmisteluvaiheeseen sekä noin viikon pituiseen toteutusvaiheeseen, jonka aikana installaatio rakennettiin, siitä nautittiin ja lopulta luovuttiin Nevadan autiomaassa.

\section{Tutkimusaineisto ja tiedonkeruu}

Tutkimuksen empiirinen aineisto muodostuu psykologisen turvallisuuden kokemusta luotaavista syvähaastatteluista, joita täydentää psykologisen turvallisuuden tasoa mittaava kysely. Kyselyyn ja haastatteluihin osallistujat pyrittiin valitsemaan siten, että he edustaisivat mahdollisimman laajasti erilaisia projektiryhmään osallistuneita henkilöitä. Projektiryhmä oli ammatilliselta taustaltaan hyvin heterogeeninen, mikä pyrittiin huomioimaan tiedonkeruussa. Projektiryh- män sukupuolijakauma oli miesvaltainen, mikä heijastui myös tutkimusaineistoon. Lisäksi tutkimusaineistoon valittiin henkilöitä, joiden aiempi kokemus Burning Man -projekteista vaihteli, ja jotka olivat liittyneet Space on Fire -työryhmään sen eri vaiheissa. Haastatteluihin osallistui 20 Space on Fire -projektiin osallistunutta henkilöä, joiden arvioitiin tarjoavan riittävän monipuolisen aineiston tutkimuksen perustaksi. Psykologisen turvallisuuden tasoa varmentava määrällinen kysely lähetettiin haastatelluille henkilöille, joista 17 vastasi siihen.

Haastatteluja hyödynnettiin syvällisen, laadullisen ymmärryksen luomiseksi psykologisesta turvallisuudesta. Haastatteluissa noudatettiin ennalta laadittua haastattelurunkoa, jossa kysyttiin (1) lyhyesti henkilön taustasta ja suhteesta Burning Man -konseptiin, (2) kokemuksista Space on Fire -projektissa: idean synnystä, organisoinnista ja sen muutoksista, henkilön omasta roolista, organisaation arvoista, kriiseistä sekä niiden käsittelystä, tunnekokemuksista ja projektin päättymisestä, ja (3) millä tavoin henkilö kokee tilapäisen organisaation toimintaan osal- 
listumisen vaikuttaneen omiin näkemyksiinsä tai toimintaansa pysyvimmissä organisaatioissa. Psykologisen turvallisuuden käsitteitä ei tuotu haastatteluissa esiin ja kyselylomake psykologisen turvallisuuden tasosta lähetettiin vasta haastattelujen jälkeen. Haastateltavia rohkaistiin kertomaan kokemuksistaan mahdollisimman avoimesti. Yksi tutkimusryhmän jäsen suoritti kaikki haastattelut keväällä 2018, ja ne kestivät keskimäärin 55 minuuttia. Pääosa haastatteluista tehtiin englanniksi. Kaikki haastattelut nauhoitettiin ja litteroitiin. Yhteiskestoltaan 18 tunnin ja 15 minuutin mittaisesta haastatteluaineistosta syntyi noin 260 liuskaa analysoitavaa tekstiä.

Määrällisen kyselyn tavoitteena oli tukea tutkimuksemme laadullista pääanalyysiä tuottamalla aikaisempiin tutkimuksiin verrannollista, numeerista tietoa psykologisen turvallisuuden toteutumisesta projektin valmistelu- että toteutusvaiheissa. Kysely sisälsi myös avoimia kysymyksiä, mikä tarjosi vastaajille mahdollisuuden kertoa kokemuksistaan nimettömästi.

Mittasimme kyselyssä psykologista turvallisuutta kahdeksan vakiintuneen, eri tekijöitä kartoittavan väittämän (Edmondson 1999) ja 5-portaisen Likert-asteikon avulla (ks. Taulukko 1). Kysymyksistä seitsemän on Edmondsonin (1999) validoimasta mittaristosta. Lisäksi kyselymme sisälsi usein käytetyn väittämän ”Ryhmän jäsenet arvostivat ja kunnioittivat toistensa panosta" (ks. esim. Team Learning and Psychological Safety Survey).

Lisäksi kyselyllä kartoitettiin jäsenten työn imua ja työhön sitoutumista sekä tunnekokemuksia. Työn imua mitattiin hyödyntäen kolme kysymystä sisältävää Utrecht Work Engagement -skaalaa (Schaufeli ym. 2019). Lisäksi henkilökohtaista sitoutumista projektiin ja työtehtäviin mitattiin kolmella väittämällä ("Olin vahvasti sitoutunut projektiin", "Olin valmis tekemään mitä vain, jotta projekti onnistuisi" ja "Mietin välillä projektista luopumista") asteikolla 1-5. Ryhmän jäsenten välisiä suhteita, yhteiseen kanssakäymiseen liittyviä tunteita ja myötätuntoista rakkautta selvitettiin Compassionate Love -skaalalla (Barsade \& O’Neill 2014), joka selvittää kuinka paljon ryhmän jäsenet ilmaisivat neljää tunnetta toisiaan kohtaan (myötätunto, hellyys, välittäminen, huolehtivaisuus) asteikolla 1 (ei koskaan) - 5 (koko ajan).

\section{Aineiston analyysi}

Laadullisen aineiston osalta analyysi noudatti teoriaohjaavan sisällönanalyysin periaatteita (Saari 2016). Teoriaohjaava sisällönanalyysi pyrkii kuvaamaan aineiston keskeisiä piirteitä sanallisesti. Se sijoittuu ääripäitä edustavien tiukan aineistolähtöisen, induktiivisen analyysin ja teorialähtöisen, deduktiivisen analyysin välimaastoon, ja noudattaa abduktiivista päättelyä (ks. Martela 2015). Ensivaiheessa aineistosta tehdään havaintoja ja tunnistetaan keskeisiä teemoja. Nämä teemat eivät välttämättä sovi tutkimusta ohjaavaan teoriaan. Seuraavassa vaiheessa empiirisestä aineistosta tehdyt havainnot pyritään liittämään teoreettisiin käsitteisiin.

Ensimmäisen tutkimuskysymyksen tavoitteena oli selvittää psykologisen turvallisuuden ilmentymistä ja sen selvittämiseksi analysoimme tekstin kohtia, joissa kuvattiin työryhmän ilmapiiriä, aloitemahdollisuuksia ja jäsenten välistä luottamusta, sekä erityisesti haastateltavien kokemusta riskinotosta ja sen seurauksista (Edmondson 1999). Toisen tutkimuskysymyksen kohdalla pyrittiin kartoittamaan psykologisen turvallisuuden mahdollistavia tekijöitä ja erityisesti ketterän luottamuksen syntymistä. Tämän osalta analyysi kohdistui projektin sisällön ja toimintatapojen (erityis)piirteiden kuvaukseen. Analyysissa edettiin aineistoa luokittelemalla ja ryhmittelemällä, ja löydettyjä teemoja tarkasteltiin aikaisemmassa tutkimuksessa tunnistettujen mahdollistajien valossa vasta analyysin myöhemmässä vaiheessa.

Määrällisellä kyselyllä kerätty taustoittava aineisto kuvaa jaetun psykologisen turvallisuuden kokemusta numeerisesti, ja se esitetään tutkimuksen tuloksissa sellaisenaan ryhmätasolla.

\section{TULOKSET}

Tutkimuksemme tulokset valottavat projektissa koettua psykologista turvallisuutta ja antavat vastauksia siihen, mitkä tekijät mahdollistivat psykologisen turvallisuuden muodostumisen. Kuvio 1 tiivistää tutkimuksen päätulokset. 


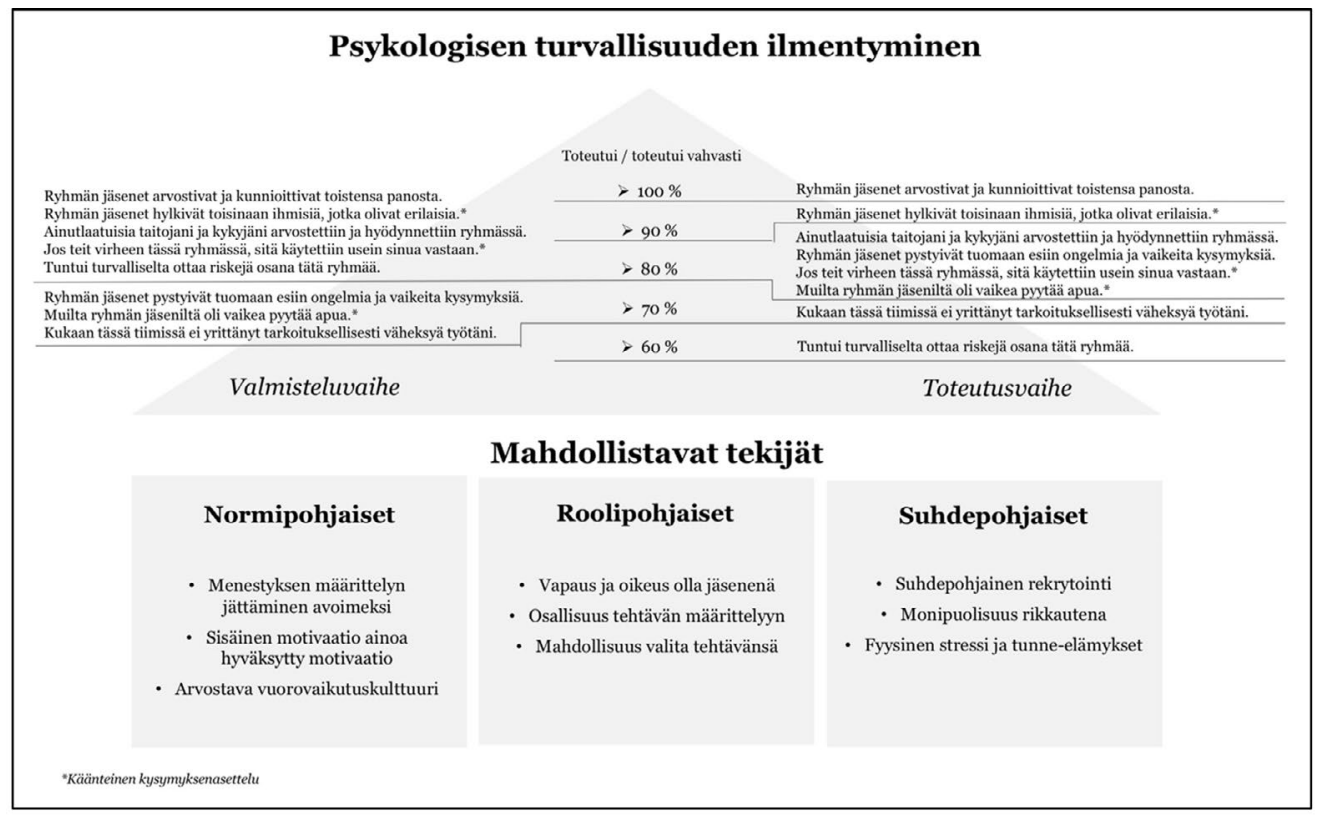

Kuvio 1. Psykologinen turvallisuus ja ketterä luottamus sen mahdollistajana.

\section{Psykologisen turvallisuuden taso projektin eri vaiheissa}

Psykologinen turvallisuus näyttäytyi erittäin vahvana läpi projektin keston (Taulukko 1). Psykologisen turvallisuuden taso vastanneiden keskuudessa oli keskimäärin 4,4 asteikolla $1-5$, mitä voidaan pitää melkeinpä radikaalin korkeana, sillä se on selvästi korkeampi kuin esimerkiksi Edmondsonin (1999) tutkimuksissaan mittaamat keskiarvot, jotka ovat asteikolta 1-7 asteikolle 1-5 transponoituina 3,8 ja 3,9. Erityisen vahvasti läpi hankkeen koettiin ryhmän jäsenten välinen arvostus ja kunnioitus sekä jäsenten erilaisten persoonien ja taustojen hyväksyminen. Ryhmän jäsenet kokivat, että heidän kykyjään sekä arvostettiin että hyödynnettiin ryhmän työssä, eivätkä ryhmän jäsenet pyrkineet satuttamaan toisiaan virheistä. Yli 80 prosenttia ryhmän jäsenistä oli samaa mieltä tai vahvasti samaa mieltä siitä, että nämä psykologista turvallisuutta mittaavat tekijät toteutuivat sekä hankkeen valmistelu- että toteutusvaiheessa.

Toteutusvaiheessa psykologisen turvallisuuden kokemuksen keskiarvo pysyi lähes samana
$(4,3)$, mutta vahvistui usean osatekijän kohdalla. Yli 90 prosenttia koki, ettei erilaisia ihmisiä hyljeksitty, ja kaikki vastaajat (100\%) olivat vähintäänkin samaa mieltä, ja 80 \% täysin samaa mieltä siitä, että jäsenten välillä vallitsi arvostus ja kunnioitus toisten työpanosta kohtaan. Lisäksi ryhmän jäsenten kokemus siitä, että ongelmia ja vaikeita kysymyksiä oli vaivatonta tuoda esille, ja että muilta ryhmän jäseniltä oli helppo pyytää apua, nousivat esille jo valmisteluvaiheesta $(<70 \%)$, ja toteutusvaiheessa yli 80 prosenttia oli samaa tai vahvasti samaa mieltä siitä, että nämä kuvasivat hankkeen ilmapiiriä.

Yksittäisten henkilöiden käytökseen tarkemmin porautuva väittämä siitä, että "kukaan tässä tiimissä ei yrittänyt tarkoituksellisesti väheksyä työtäni” koettiin läpi hankkeen kohtalaisen paikkansapitäväksi, ja yli 70 prosenttia allekirjoitti olevansa siitä samaa tai vahvasti samaa mieltä. Tulos oli kuitenkin alhaisempi ja vastausten hajonta suurempaa kuin useimpien muiden väittämien kohdalla. Ainoa osa-alue, joka laski selvästi toteutusvaiheeseen edettäessä, oli tunne, että osana ryhmää oli turvallista ottaa riskejä; valmisteluvaiheessa näin koki yli 80 prosenttia vastanneista, mutta toteutusvaiheessa vain kaksi 
Taulukko 1. Psykologisen turvallisuuden ilmentyminen Space on Fire -projektissa

\begin{tabular}{|c|c|c|c|c|c|}
\hline Psykologisen turvallisuuden ilmentymiä & $\begin{array}{r}\text { Vahvasti } \\
\text { eri mieltä }\end{array}$ & $\begin{array}{r}\text { Eri } \\
\text { mieltä }\end{array}$ & $\begin{array}{r}\text { En osaa } \\
\text { sanoa }\end{array}$ & $\begin{array}{r}\text { Samaa } \\
\text { mieltä }\end{array}$ & $\begin{array}{r}\text { Vahvasti } \\
\text { samaa } \\
\text { mieltä }\end{array}$ \\
\hline \multicolumn{6}{|c|}{$\begin{array}{l}\text { Ryhmän jäsenet pystyivät tuomaan esiin ongelmia ja } \\
\text { vaikeita asioita. }\end{array}$} \\
\hline Valmisteluvaiheessa & - & $6 \%$ & $24 \%$ & $41 \%$ & $29 \%$ \\
\hline Toteutusvaiheessa & - & $7 \%$ & $7 \%$ & $60 \%$ & $26 \%$ \\
\hline \multicolumn{6}{|c|}{ Tuntui turvalliselta ottaa riskejä osana tätä ryhmää. } \\
\hline Valmisteluvaiheessa & - & - & $18 \%$ & $12 \%$ & $70 \%$ \\
\hline Toteutusvaiheessa & - & $13 \%$ & $20 \%$ & $13 \%$ & $54 \%$ \\
\hline \multicolumn{6}{|c|}{$\begin{array}{l}\text { Kukaan tässä tiimissä ei yrittänyt tarkoituksellisesti } \\
\text { väheksyä työtäni. }\end{array}$} \\
\hline Valmisteluvaiheessa & - & $6 \%$ & $23 \%$ & $12 \%$ & $59 \%$ \\
\hline Toteutusvaiheessa & $6 \%$ & $14 \%$ & $6 \%$ & $27 \%$ & $47 \%$ \\
\hline \multicolumn{6}{|c|}{$\begin{array}{l}\text { Ainutlaatuisia taitojani ja kykyjäni arvostettiin ja } \\
\text { hyödynnettiin ryhmässä. }\end{array}$} \\
\hline Valmisteluvaiheessa & - & $6 \%$ & $12 \%$ & $12 \%$ & $70 \%$ \\
\hline Toteutusvaiheessa & - & - & $13 \%$ & $27 \%$ & $60 \%$ \\
\hline \multicolumn{6}{|c|}{$\begin{array}{l}\text { Ryhmän jäsenet arvostivat ja kunnioittivat toistensa } \\
\text { panosta. }\end{array}$} \\
\hline Valmisteluvaiheessa & - & - & $12 \%$ & $23 \%$ & $65 \%$ \\
\hline Toteutusvaiheessa & - & - & - & $20 \%$ & $80 \%$ \\
\hline \multicolumn{6}{|c|}{$\begin{array}{l}\text { Jos teit virheen tässä ryhmässä, sitä käytettiin usein } \\
\text { sinua vastaan. }{ }^{*}\end{array}$} \\
\hline Valmisteluvaiheessa & $71 \%$ & $23 \%$ & $6 \%$ & - & - \\
\hline Toteutusvaiheessa & $60 \%$ & $27 \%$ & $13 \%$ & - & - \\
\hline \multicolumn{6}{|c|}{$\begin{array}{l}\text { Ryhmän jäsenet hylkivät toisinaan ihmisiä, jotka } \\
\text { olivat erilaisia. }{ }^{*}\end{array}$} \\
\hline Valmisteluvaiheessa & $53 \%$ & $29 \%$ & $18 \%$ & - & - \\
\hline Toteutusvaiheessa & $53 \%$ & $40 \%$ & $7 \%$ & - & - \\
\hline \multicolumn{6}{|c|}{ Muilta ryhmän jäseniltä oli vaikea pyytää apua. * } \\
\hline Valmisteluvaiheessa & $58 \%$ & $18 \%$ & $18 \%$ & - & $6 \%$ \\
\hline Toteutusvaiheessa & $53 \%$ & $33 \%$ & - & $7 \%$ & $7 \%$ \\
\hline
\end{tabular}

*Nämä kysymykset ovat käänteisiä eli 'vahvasti eri mieltä' on osoitus psykologisen turvallisuuden toteutumisesta.

kolmesta. Tämä on mielenkiintoinen havainto, etenkin kun kysymys riskistä osuu tiukasti psykologisen turvallisuuden käsitteen ytimeen. Yksi mahdollinen selitys on projektin erityispiirteissä, mistä johtuen toteutusvaiheen olosuhteet olivat fyysisesti erittäin rankat. Aurinko porotti autiomaassa niin kuumana, että osa ryhmän jäsenistä kertoi haastatteluissa pyörtyneensä ja saaneensa auringonpistoksen. Osa kuvasi myös ryhmän rakennustaidottomuuden, kiireen ja väsymyksen sekä tiukkojen turvajärjestelyiden puuttumisen tuoneen epäilyksen siitä, että va- kavammatkaan onnettomuudet eivät olisi poissuljettuja.

Psykologisen turvallisuuden ohella hankimme vertailukelpoista tietoa myös työhön sitoutumisesta. Tulokset indikoivat erittäin korkeaa sitoutuneisuutta, keskiarvon ollessa valmisteluvaiheessa 4,0 ja toteutusvaiheessa 4,3 asteikolla 1-5. Tarkempi tulosten tarkastelu osoitti, että valmisteluvaiheessa vastaajat ilmoittivat yli 80 prosenttisesti olevansa samaa tai vahvasti samaa mieltä väittämien "Olin innostunut tehtävistäni", "Olin erittäin sitoutunut projektiin" ja "Olin ha- 
lukas tekemään mitä vain projektin onnistumiseksi" kanssa. Sitoutuneisuuden osalta henkilöt ilmoittivat olevansa vahvan sitoutuneita 4,2 keskiarvolla suunnitteluvaiheessa ja 4,5 keskiarvolla toteutusvaiheessa. He ilmoittivat olevansa valmiita tekemään mitä vain projektin onnistumiseksi keskiarvolla 4,0 suunnitteluvaiheessa ja 4,2 toteutusvaiheessa. Projektin keskeyttämisen mahdollisuuden osalta keskiarvo oli 1,8 suunnitteluvaiheessa ja 1,7 toteutusvaiheessa. Sitoutuneisuutta koettiin siis vielä vahvemmin projektin toteutusvaiheessa, jolloin installaatio rakennettiin. Samoin työn imun osalta keskiarvo nousi suunnitteluvaiheen 4,0 :sta toteutusvaiheen 4,3:een, jotka molemmat indikoivat korkeaa työn imua asteikon ollessa 1-5.

Myös numeeriset tulokset koskien myötätuntoista rakkautta kertoivat, että ryhmän jäsenten välinen kanssakäyminen oli hyvin tunnepitoista. Valmisteluvaiheessa myötätuntoisen rakkauden keskiarvo oli 3,7 asteikolla 1-5, ja nousi 3,9:ään toteutusvaiheessa. Yli $90 \%$ vastaajista koki, että ryhmän jäsenet kohtelivat toisiaan usein, tai vähintäänkin joskus, lämpimästi, välittävästi ja myötätuntoisesti, ja lähes 90 prosentin mukaan myös hellyyttä osoittaen. Projektin toteutusvaiheessa näiden tunteiden kokeminen vahvistui, ja yhä useampi vastaaja ilmoitti ryhmän jäsenten kohtelevan toisiaan näin usein tai jopa aina.

\section{Psykologisen turvallisuuden ilmentyminen}

Haastattelut tukivat tulosta vahvasta psykologisesta luottamuksesta ihmisten välillä ja tarjosivat lisätietoa siitä, miten psykologista turvallisuutta kuvattiin. Yleisesti ottaen haastattelut vahvistivat käsitystä, että projektin koettiin tarjoavan ympäristön, jossa riskinotto on sallittua, ja kaikki saavat ilmaista mielipiteitään ja tehdä aloitteita ilman tuomitsemisen tai epäonnistumisen pelkoa. Työryhmän ilmapiiriä kuvattiin muun muassa seuraavasti:

"Oli todella helppo ehdottaa jotakin ja heittää itsensä täysillä peliin ja esittää jopa tyhmiä ideoita, kun kukaan ei hyökännyt sinua vastaan." (Haastateltava 11)
"Minusta tuntui, että kaikki pysyivät ihan vaan olemaan omia itsejään ja tuomaan pöytään sen mitä osasivat." (Haastateltava 13)

"Aina, kun jollain oli idea, niin kaikki vaan rohkaisivat, että joo, kokeile, tee prototyyppi, piirrä se taululle tai esitä jotenkin." (Haastateltava 15)

"Ihmiset olivat todella avoinna kaikelle, ja eivät ajatelleet seuraamuksia, vaan ainoastaan sitä, että tekivät sitä mikä tuntui oikealta, ja se oli jotain mitä heidän vain piti tehdä. (Haastateltava 15)

"Opin epäonnistumaan, todellakin opin. Ja se oli ihan ok yhteisölle, kun epäonnistuin, kaikki oli ihan hyvin." (Haastateltava 8)

"Se oli organisaatio, jossa oli ok tehdä virheitä ja opittiin nopeasti." (Haastateltava 4)

Merkillepantavaa on, että tuloksemme viittaavat siihen, että vahva kokemus psykologisesta turvallisuudesta jätti osallistujiin pysyvän jäljen. Space on Fire -projektiin osallistuneet henkilöt huomasivat muutoksia sekä arvoissaan että konkreettisissa toimintatavoissaan. Ryhmän jäsenyys syvensi osallistujien uskoa itseilmaisun tärkeyteen, ja lisäsi luottamusta muihin ihmisiin muistuttamalla osallistujia siitä, että on olemassa ympäristöjä, joissa voi olla vapaa ja arvostettu.

"Tässä yhteisössä on tosi mielenkiintoisia ihmisiä, mutta se on enemmän vielä se toisia tukeva ja tarpeeksi hullu ympäristö, joka on tärkeää - et vain ikinä sano ei', vaan aina, että 'joo!' - ja se on vaan niin virkistävä tila, jossa voi olla." (Haastateltava 1)

"...se innostus, päättäväisyys, sen pitäisi olla ihan standardi tästä eteenpäin. Teen kaikkeni, että saisin luotua sen tiimihengen aina, kun teen yhteistyötä muiden kanssa." (Haastateltava 7)

”...päästää irti siitä, kuka ajattelen, että minun täytyy olla, tai täytyy yrittää olla... se antoi minulle käsityksen omasta identiteetistäni ihan uudella tavalla, ei niin kuin mikään 'feikki' valeidentiteetti" (Haastateltava 13) 
"Joka kerran, kun joku meistä ottaa yhteyttä johonkin toiseen, niin aina tietää, että toisella on pelkästään hyvät aikeet ja voit luottaa siihen." (Haastateltava 15)

”...miten tuoda se yhteisöllisyyden tunne 'oikeaan' maailmaan, niin, että joku päivä voimme kutsua sitä oikeaksi maailmaksi, sen suuntaista minä toivon." (Haastateltava 14)

\section{Ketterä luottamus psykologisen turvallisuuden mahdollistajana}

Tutkimuksen tulokset toivat pintaan useita erityisesti Space on Fire -projektin erityispiirteitä, jotka tukivat ryhmän kykyä toimia nopeasti yhdessä tavalla, joka loi psykologista turvallisuutta. Nämä mahdollistajat jakautuivat luontevasti normipohjaisiin, roolipohjaisiin ja suhdepohjaisiin mahdollistajiin. Ne voidaan siis jakaa niihin kolmeen osa-alueeseen, joiden on esitetty edistävän ketterän luottamuksen syntymistä tilapäisorganisaatioissa. Esittelemme ensin normipohjaisia mahdollistajia, jotka liittyvät läheisesti projektin päätavoitteeseen ja konseptiin. Tämän jälkeen keskitymme roolipohjaisiin ja suhdepohjaisiin tekijöihin, jotka kuvaavat työryhmän tehtävienjakoa sekä jäsenten välistä kanssakäymistä.

\section{Normipohjaiset mahdollistajat}

Haastatteluissa nousi esille useita normipohjaisia tekijöitä, jotka liittyivät projektin kontekstiin ja tehtävän luonteeseen, ja tukivat psykologisen turvallisuuden kokemusta. Tärkeä tekijä oli se, että Space on Fire -projekti oli osa Burning Man -kokonaisuutta, jota ohjaavat tietyt radikaalia itseilmaisua edustavat periaatteet. Eri maissa toteutettavat osaprojektit noudattavat näitä periaatteita oman tulkintansa mukaan. Osalle Space on Fire -projektiin osallistuneista henkilöistä Burning Manin toimintafilosofia oli tuttua, ja he osasivat luottaa myös tämän tuomiin raameihin. Keskeisiä periaatteita (normeja) olivat muun muassa, että projektissa työskentely perustui vapaaehtoisuuteen ja toiminnassa korostettiin itseohjautuvuutta. Tämä merkitsi sitä, että hankkeen tarkoitus ja kokonaisuus oli määritelty väljästi visioivan tarinan muotoon, jonka kaikki tunsivat, mutta muuten hankkeen konsepti oli avoin ja sen sisältö määräytyi jäsenten aloitteiden perusteella. Toisin sanoen, kenelläkään ei ollut valtaa asettaa projektille muita tavoitteita kuin ne, jotka ryhmä yhdessä määrittelee, eikä kenenkään olisi ollut hyväksyttävää käyttää projektia esimerkiksi oman uransa tai liiketoimintansa edistämiseen. Näiden institutionaalisten puitteiden pohjalta tunnistimme haastatteluista kolme normipohjaista mahdollistajaa, jotka tukivat psykologisen turvallisuuden muodostumista.

Menestyksen määrittelyn jättäminen avoimeksi. Vaikka Space on Fire -projektissa oli korkea tavoitetaso, ja se toteutettiin vaativissa olosuhteissa, projektin sisältö ja konsepti olivat pitkään hyvin avoimia, eikä sen myötä ollut olemassa yksiselitteisiä määritteitä sille, mitä voitaisiin pitää onnistumisena ja menestymisenä ja mikä puolestaan laskettaisiin epäonnistumiseksi. Tulostemme perusteella arvoimme menestyksen väljän määritelmän tukeneen osallistujien kokemusta, että hankkeessa oli turvallista ottaa riskejä. Osallistujat pitivät tärkeimpänä onnistumisenaan sitä, että projekti saatiin toteutettua, eivätkä he kokeneet - monista vastoinkäymisistä huolimatta - moniakaan asioita epäonnistumisina.

"Kun ei ole mitään erityistä, määriteltyä päämäärää, vaan on vain, että ok, tätä kohti mennään, ja tätä abstraktia asiaa kohti, ja mitä vain saavutamme sinnepäin, on ok." (Haastateltava 9)

"Suurin [onnistuminen] on tietysti se, että saimme lopulta kaiken tehtyä ja valmiiksi." (Haastateltava 16)

"Eli tavallaan se, ettei ongelmia vastustettu, teki helpoksi, että navigoimme nopeasti uusiksi, sitä vissiin kutsutaan iteroinniksi tai nopeaksi palautteenannoksi, jossa voi aina asemoitua uudelleen. Eli oikeastaan mikään ei ikinä tuntunut ongelmalta. (Haastateltava 13)

\footnotetext{
"Space on fire oli malliesimerkki, ja myös epäonnistumisista. Yli 80 prosenttia kaikesta, mitä sanoin epäonnistui. Ja kuitenkin projekti onnistui, ja kaikki hyväksyivät epäonnistumiset." (Haastateltava 8)
} 
"En oikeastaan pidä koko sanonnasta, että tähtäsimme tähtiin ja päädyimme kuuhun, mutta niin me periaatteessa tehtiin." (Haastateltava 3)

Sisäinen motivaatio ainoa hyväksytty motivaatio. Projekti toteutettiin vapaaehtoisvoimin, eikä kukaan saanut siitä palkkaa; päinvastoin osallistujat investoivat projektiin omia henkisiä, fyysisiä että taloudellisia pääomiaan. Projektin vapaaehtoisuus oli reunaehto, jossa ulkoisten pakkojen ja kannusteiden puuttuminen sai ryhmän jäsenet luottamaan toistensa motivaatioihin ja "hyvään tahtoon" toimia yhteisön eduksi.

"Se fakta, että jokainen oli mukana vain, koska halusi olla, ja he halusivat käyttää aikaansa ja rahaansa ja kaikkea, ja se on vain, että heidän motivaationsa on hyvin erilainen." (Haastateltava 2)

"Sen sijaan, että olisi ulkoisia motivaattoreita, kuten palkka tai bonukset tai jotakin sellaista, niin kaikki olivat vain pääasiassa mukana sisäisen motivaation takia." (Haastateltava 15)

"Kukaan tässä tiimissä ei ollut mukana hankkiakseen jotakin henkilökohtaista hyötyä, se oli ryhmä̈̈ varten, kaikkien jäsenten hyväksi, jonkun hyvän puolesta, jonkun paremman." (Haastateltava 10)

Arvostava vuorovaikutuskulttuuri. Haastateltavat toivat arvomaailmaa kysyttäessä esille psykologisen turvallisuuden mukaisia periaatteita, kuten toisten kunnioittaminen, arvostelun välttäminen ja epäonnistumisen salliminen.

"Kaikkien pitäisi voida tutkiskella itseään ja mihin he pystyvät... ... tarjoamalla tällainen paikka, jossa saat ja voit oikeasti epäonnistua." (Haastateltava 2)

"Yritän kunnioittaa toisia ihmisiä, yritän antaa heille oman tilan... Yritän, ainakin toivon, että pystyn ja yritän, antaa vinkkejä ja ideoita omalta alaltani, jossa uskon olevani hyvä." (Haastateltava 3)

"Haluan uskoa, että olen ihminen, joka ei ammu alas toisten ideoita." (Haastateltava 1)

\section{Roolipohjaiset mahdollistajat}

Projektin työnjako oli vahvasti osallistujien itsensä kädessä. Projektin johtohahmot pyrkivät jossain määrin varmistamaan, että keskeiset tehtävät olisivat jonkun hoidossa, mutta toisaalta kenenkään ei valmisteluvaiheessa edellytetty ottavan tiettyä roolia - ja ketään ei kielletty tarttumasta haluamaansa tehtävään. Tämä roolituskäytäntö loi vahvaa omistajuutta hankkeesta kolmella tavalla: Avoin osallistuminen sai osallistujat kokemaan, että heillä on oikeus jäsenyyteen. Koska projektin tehtäväkokonaisuus oli hyvin väljä, sen määrittely kuului yhtäläisesti kaikkien jäsenten rooliin. Oikeus ottaa vastuuta lisäsi jäsenten sitoutuneisuutta. Vaikka projektin jäsenten roolit eivät olleet etukäteen tiedossa tai tarkkaan määriteltyjä, jokainen tiesi omat tehtävänsä ja vastuunsa, eikä näissä ilmennyt osallistujien keskuudessa epätietoisuutta.

Vapaus ja oikeus olla jäsenenä. Toisin kuin työpaikkoja tai jopa tavoitteellisia harrastusryhmiä täytettäessä, jäsenten ei tarvinnut täyttää erityisiä kriteereitä osallistuakseen projektiin. Osallistujien rekrytoinnissa noudatettiin periaatetta, että hankkeeseen sai osallistua kuka vain siitä kiinnostunut. Avoin osallistuminen sai jäsenet kokemaan, että heidän ei tarvitse ansaita paikkaansa kuuluakseen ryhmään. Heidän asemansa oli turvattu, eikä sen puolesta tarvinnut pelätä. Tämä kokemus tuki psykologisen turvallisuuden tunnetta.

"Ihan loppuun asti pidimme sen ihan avoimena, eli periaatteessa kutsuimme kaikki osallistumaan ja liittymään, ja pidimme kokoukset avoimina myös. Eli ei oikeastaan vaikuttanut kuka oli kiinnostunut ja mikä heidän taustansa oli ja niin edelleen, me vaan sanottiin, että ok, me tavataan kaikki sellaisina kuin ne tulee, ja katsotaan miten käy. Jos tuntuu siltä, että haluat tulla mukaan." (Haastateltava 15)

"Eli hierarkiaa ei ollut ollenkaan. Minun ei tarvinnut kiivetä mitään tikapuita tavatakseni oikeat ihmiset ja voittaakseni heidän luottamuksen, olin vaan yksi joukosta heti, kun tulin paikalle." (Haastateltava 7)

"Ja he ymmärsivät, että kaikille on rooli ja aina riittää kaikille tekemistä." (Haastateltava 15) 
Osallisuus tehtävän määrittelyyn. Edellä kuvatun avoimen konseptin myötä osallistujat kokivat voivansa osallistua hankkeessa keskeisiin tehtäviin ja kokonaisuuden määrittelyyn. Oli selvää, ettei kukaan ollut määräävämmässä asemassa suhteessa toiseen, vaan hankkeen sisältö rakentuisi ehdotusten realistisuuden ja toteutuskelpoisuuden sekä jäsenten innostuksen, halujen ja sitoutumisen perusteella. Tulosten perusteella näyttää, että tasavertainen osallisuus loi kokemuksia siitä, että kaikkien ideoita kuunnellaan ja kehitetään yhdessä eteenpäin. Tämä loi turvallisuuden tunnetta ja luottamusta siihen, että aloitteissaan voi ottaa riskejä eikä ehdotusten tarvitse olla valmiiksi pureskeltuja.

"Ja sitten me vaan aloimme pitää säännöllisiä kokouksia joka viikko ja aloitettiin varojenkeruu, ja sitten, siitä se kehittyi pikkuhiljaa... viikoittaisia kokouksia ja sitten tehtiin design ja keskusteltiin millainen sen pitäisi olla." (Haastateltava 2)

"Ja sitten erilaisia ihmisiä, eri aloilta päätyi yhteen ja alettiin yhdessä ratkaista sitä juttua ja mitä me oikeastaan voidaan tehdä tai mitä sen pitäisi olla ja mikä on mahdollista. Ja miten saadaan kaikki palat yhteen." (Haastateltava 3)

"Minä olin siellä tekemässä päätöksiä kaikkien joukossa, ja me oltiin kaikki tasa-arvoisia siinä todellakin ja koko projektin ajan...saatiin vaikuttaa voisiko sen tehdä. Jos pystyy, niin sitten se tehdään, se oli mentaliteetti." (Haastateltava 13)

"[päätöksenteossa] sanoisin, että suurin määrittelevä tekijä oli yksinkertaisesti, että tekikö joku sen homman vai ei." (Haastateltava 9)

Mahdollisuus valita tehtävänsä. Johtamismalli oli vahvasti yhteisöllinen, ja hankkeessa annettiin jokaisen osallistua haluamallaan tavalla. Avoin vastuunotto merkitsi sitä, että velvollisuuksien sijaan Space on Fire -osallistujilla oli oikeuksia ja mahdollisuuksia, mikä tuki heidän itseluottamustaan. Mahdollisuus ottaa vastuu kaikista haluamistaan tehtävistä - ja toisaalta vain niistä - edesauttoi ryhmän jäseniä tunnistamaan omia vahvuuksiaan ja hyödyntämään osaamistaan täysimääräisesti.

"Kaikkien pitäisi saada osallistua sillä tavalla kuin he haluavat, eikä ihmisiä voi jättää ulkopuolelle ja sanoa, että 'ei', sinä et voi tehdä sitä, jos joku todella haluaa." (Haastateltava 2)

"Se oli aika itseohjautuvaa, että millaisia rooleja ihmiset halusivat ottaa." (Haastateltava 15)

"Mä vaan menin sinne kokoukseen ja siellä sanottiin, että tällaista me ollaan tekemässä, ja sä saat tehdä ja toteuttaa ihan mitä vaan haluat, ja olin vaan, että selvä." (Haastateltava 13)

"Se oli oikeastaan ainoa organisoitunut osuus, että pidämme kokouksia. Ja sitten sovimme, mitä tehdään, ja sitten ihmiset tekevät juttun$s a$, ja sitten tavataan taas. Eli ei ollut mitään, että 'mikset tehnyt tätä?'. Ihmiset tekevät, mitä pystyvät, ja sitten sopeudumme tilanteeseen." (Haastateltava 10)

\section{Suhdepohjaiset mahdollistajat}

Suhdepohjaisia tekijöitä tarkasteltaessa on olennaista hahmottaa sosiaalisen kanssakäymisen ja organisatorisen rajapinnan yhteispeli. Tämä näyttäytyi jäsenten rekrytoinnissa, jossa uusia jäseniä hankittiin lähinnä suhdeverkkojen kautta. Projektin osallistujat pääsivät toimimaan oman ammattiympäristönsä ulkopuolelta tulevien ihmisten kanssa, ja huomasivat eri aloilta kumpuavan osaamisen ja taitojen merkityksen. Erittäin keskeiseksi piirteeksi nousi lisäksi se, millä tavoin hyvin vaativa projekti loi henkilöille jaettuja kokemuksia, ja jopa jaettuja koettelemuksia, jotka syntyivät, projektin "pakottaessa" osallistujat äärirajoilleen ja paljastamaan kaikki omat kykynsä - ja niiden rajallisuuden - rankoissa toteutusvaiheen olosuhteissa Nevadan autiomaassa.

Suhdepohjainen rekrytointi. Jokainen osallistuja tunsi entuudestaan ainakin jonkun toisen, joka toimi ikään kuin takuuna siitä, että hanke olisi merkityksellinen osallistujalle. Suhdepohjaisen rekrytoinnin myötä uudet osallistujat odottivat hankkeeseen liittyessään sen tarjoavan 
ympäristön, jossa saa uusia tuttavuuksia sekä mahdollisuuden tarjota sekä kehittää osaamistaan yhteisen hyvän edistämiseen. Tämä oli usein motivaationa osallistua ryhmän toimintaan.

"Melkein jokainen kuuli siitä joltain kaverilta, ja liittyi ihan saman tien." (Haastateltava 12)

"Tavallaan kiinnostuin, kun tiesin, että siellä olisi paljon ihmisiä, joita tunsin ja kivoja ihmisiä, ja mahdollisesti jotain kiinnostavaa tekemistä." (Haastateltava 9)

"Oli mahdollisuus tarjota jotakin kaikille muille osallistujille, ja se tuntui sellaiselta, mikä mun pitäisi tehdä." (Haastateltava 7)

Monipuolisuus rikkautena. Rekrytointitapa ja avoin osallistuminen, joka ei edellyttänyt jäseniltä tiettyä osaamista johti monipuoliseen kokoonpanoon. Jäsenet pääsivät jakamaan omaa osaamistaan oman ammattialansa ulkopuolisille, joiden silmissä heidän taitonsa näyttivät erityisiltä. Samaan aikaan he saivat mahdollisuuden oppia taidoista ja osaamisesta toisilta aloilta. Tämän seurauksena osallistujat tunsivat voivansa luottaa ryhmän muiden jäsenten ammattitaitoon, eikä kukaan kokenut olevansa erilainen kuin "kaikki muut".

"Noin 50 hengen ryhmä, ja kaikki ammattilaisia jollakin alalla, eli meillä oli erittäin lahjakkaita ihmisiä." (Haastateltava 15)

"Ihmiset eivät välttämättä puhuneet niin paljoa, mutta kun he puhuivat, niin se oli sellaista, mikä kumpusi heidän osaamisestaan ja tiedoistaan." (Haastateltava 13)

"Osallistujien laatu oli kerrassaan ällistyttävä. Koska, kun mennään autiomaahan, keskelle ei mitään, toiselle mantereelle, niin siitä tulee tiettyjä vaatimuksia... persoonallisuus, mitä osaa tehdä, ja niin edelleen. Eli Space on Fire -organisaatiossa ihmiset olivat todella älykkäitä, luovia, kunnianhimoisiakin. ... En ole ikinä nähnyt niin montaa superihmistä." (Haastateltava 6)
Fyysinen stressi ja tunne-elämykset. Projektin erittäin korkeat tavoitteet ja mittava työmäärä vaativat ryhmän jäseniä venymään kestävyytensä äärirajoille, ja ammentamaan yhteistyön ja toistensa kannustamisen tuomasta voimasta. Toteutusvaiheessa nälän, väsymyksen, epätoivon ja onnistumisen tuomat voimakkaat tunnekokemukset tekivät ihmisistä paljaita, mikä näytti monelle jäsenelle uusia puolia heistä itsestään - paljastaen ne samalla suodattamattomina toisille ryhmän jäsenille. Nämä kokemukset hitsasivat osaltaan jäseniä yhteen, ja projektin loppuunsaattaminen toimi todisteena siitä, että riskinotto ja itsensä peliin laittaminen ja toisiin luottaminen tuottivat positiivisia tuloksia.

"Työmäärä, joka meidän täytyi tehdä siellä, oli todella massiivinen." (Haastateltava 6)

"Installaatio itsessään oli todella kunnianhimoinen ja se oli valtava ja kova työ." (Haastateltava 11)

"Alku oli hidasta, koska meillä ei ollut leiriä, meillä ei ollut keittiötä, meillä ei ollut varjoa, jonka suojassa levätä, joten luulen, että siinä vaiheessa, ehkä kolmantena tai neljäntenä päivänä, moni oli varmaan lähellä luovuttaa, että ei tämä onnistu." (Haastateltava 15)

"Sinulla ei todellakaan ole muuta vaihtoehtoa kuin luottaa toisiin ja tukea toisia. Koska tarvitse kaiken avun, jonka voit saada, niin et voi jättää ketään ulkopuolelle." (Haastateltava 7)

"Kun paikalla ei ole montaa ihmistä, keskellä autiomaata, heräät aikaisin aamulla...aloitat työnteon ja kahteen päivään, et tee mitään muuta kuin kävelet ympyrää...kuin härkä, tai entisajan orjat. Niin, mutta joo, se oli mahtava ajanjakso." (Haastateltava 1 )

"Tunteellisin elämys, jonka olen kokenut. Hyvässä ja pahassa. Paljon negativisia tunteita, paljon positivisia tunteita. Kun saimme koko homman valmiiksi, mutta kun poltimme sen maan tasalla, se oli, nähdä tuhansien ihmisten olevan liikuttuneitta siitä kauneudesta, jonka olimme rakentaneet, se oli todella erityistä." (Haastateltava 7) 


\section{JOHTOPÄÄTÖKSET}

Tutkimuksemme tavoitteena oli tarkastella psykologisen turvallisuuden ilmentymistä ja sen mahdollistavia tekijöitä tilapäisorganisaatiossa. Psykologinen turvallisuus merkitsee sitä, että tiimin jäsenet jakavat uskomuksen tiimistä turvallisena paikkana ottaa ihmisten välisiä riskejä (Edmondson 1999). Psykologinen turvallisuus parantaa sekä yksilöiden hyvinvointia, kuten tiimin jäsenten kokemaa merkityksellisyyttä, sekä tiimin toimintaa kokonaisuutena, kuten sen oppimiskykyä, informaation jakamista, luovuutta ja tuloksellisuutta (Barsade \& Gibson 2007; Frazier ym. 2017). Tilapäisorganisaatio, jossa ryhmän jäsenet eivät ole aiemmin työskennelleet yhdessä eivätkä odota näin tapahtuvan tulevaisuudessa (Goodman \& Goodman 1976), luo haasteita psykologisen turvallisuuden syntymiselle. Tutkimuksemme tulokset osoittavat keskeisiä tekijöitä, jotka tukevat psykologisen turvallisuuden muodostumista tilapäisorganisaatiossa, joka toimi itseohjautuvasti ja ilman hierarkkista organisaatiomallia (Lee \& Edmondson 2017; Martela 2019; Martela \& Kostamo 2017).

\section{Psykologinen turvallisuus itseohjautuvissa tilapäisorganisaatioissa}

Tutkimus pureutuu laadullisen tutkimuksen keinoin tilapäisorganisaation käytäntöihin. Tällä tavoin se täydentää aikaisempaa psykologisen turvallisuuden tutkimusta, joka on pääasiassa ollut määrällistä (Edmondson \& Lei 2014; Frazier ym. 2017) ja osoittaa keinoja, joilla voidaan empiirisesti tutkia tilapäistä ilmiötä (Bakker ym. 2010). Tutkimuksen tulokset osoittavat, että psykologinen turvallisuus oli projektissa erityisen voimakasta ja pitkäkestoista - radikaalia. Empiirinen konteksti tarjoaa siten ääriesimerkin menestyksekkäästi psykologista turvallisuutta synnyttäneestä tilapäisorganisaatiosta. Tämänkaltaiset ääriesimerkit ovat usein erityisen valaisevia, kun pyritään syventämään ymmärrystä jostakin tietystä ilmiöstä (Yin 2009, 47).

Tulosten perusteella ketterä luottamus (swift trust) mahdollistaa psykologisen turvallisuuden syntymisen tilapäisorganisaatiossa (Bakker 2010; Frazier ym. 2017; Meyerson ym. 1996). Tulokset tukevat aiempaa kirjallisuutta, jonka mukaan ketterä luottamus syntyy normi-, rooli- ja suhdepohjaisten tekijöiden avulla. Samaan aikaan tutkimuksen tulokset täydentävät aikaisempaa ymmärrystä siitä, millaisia normeja, rooleja ja suhteita psykologisen turvallisuuden muodostuminen edellyttää.

Aiemmassa tutkimuksessa (Grabher 2002) on esitetty, että menestyksekkäässä tilapäisorganisaatiossa normipohjaisten tekijöiden on tarjottava tiimin jäsenille selkeät rajat, normit ja regulaatiot. Tutkimuksemme osoittaa, että tiimin jäsenet kaipaavat tiettyjä raameja toiminnalle, jotta tiimin välinen psykologinen turvallisuus pääsee syntymään. Näiden ei kuitenkaan välttämättä tarvitse muodostaa "selkeitä rajoja", vaan ne voivat olla vähemmän tarkasti määriteltyjä arvoja, periaatteita, visioita ja toimintatapoja, joihin jäsenet voivat nojautua. Tuloksemme osoittavat myös, että tilapäisorganisaation roolijakoon (Bechky 2006) ei ole välttämätöntä käyttää suunnattomia suunnitteluresursseja tai ylhäältä tapahtuvaa johtamista, joka ennakoisi tarkasti millaisia tehtäväkokonaisuuksia on tarpeen luoda. Sen sijaan projektissa noudatettu roolijako ja käytännöt voivat muodostua tiimin jäsenten itsensä kautta. Ihmisten mahdollisuus valita roolinsa lisää omistajuutta ja osaamisen tunnetta, mikä vahvistaa psykologista turvallisuutta. Suhdepohjaisten tekijöiden kohdalla tunnistimme psykologista turvallisuutta tukevia seikkoja, jotka syntyivät "jäsenten aiemmin luomista suhteista" (Jones \& Lichtenstein 2008). Lisäksi tuloksemme nostivat esiin tilapäisorganisaation toimintaan liittyviä piirteitä, jotka vahvistivat henkilökohtaisten suhteiden syntymistä ja lujittumista osallistujien välille projektin aikana. Näitä olivat mm. henkisesti ja fyysisesti vaativat olosuhteet, jotka edellyttivät, että tiimin jäsenet toimivat "yhtenä rintamana" selvitäkseen tehtävästä.

Onkin mielenkiintoista huomata, että tutkimuksemme tulokset tuovat esille tekijöitä, jotka antavat tilaa ja mahdollistavat psykologisen turvallisuuden syntymistä, mutta toisaalta myös tekijöitä, jotka ikään kuin "pakottavat" tiimin jäsenet toimimaan toisiinsa luottaen ja ottamaa riskejä, jotka tuntuvat yhdessä otettuina turvallisilta. Aikaisempi psykologisen turvallisuuden tutkimus (Edmondson \& Lei 2014) on esittänyt, että tehtävän epävarmuus ja resurssien puute vaikuttavat psykologisen turvallisuuden muodostumiseen. Tutkimuksemme osoittaa, että 
tehtävän epävarmuus ja määrittelemättömyys eivät välttämättä ole negatiivisia tekijöitä, vaan konseptin avoimuus voi osaltaan lisätä jäsenten turvallisuudentunnetta. Resurssien rajallisuus voi samoin osoittautua tekijäksi, joka ikään kuin hitsaa jäseniä yhteen ja ohjaa heitä luottamaan kanssaihmisiinsä. Samalla tavoin tuloksemme korostavat, että tiimin kokoonpanon ja tiimin johtamisen osalta avoin osallistumismahdollisuus ja avoin vastuunotto luovat positiivisia vaikutuksia, vaikka niiden voisi ajatella sisältävän riskin siitä, että projektissa on liikaa epäselvyyttä ja päättämättömyyttä. Tuloksemme viittaavat siihen, että organisaatiomalleissa, joissa ihmiset pääsevät toimimaan vahvan itseohjautuvasti ilman tiukkaa ylhäältä tulevaa ohjausta (Lee \& Edmondson 2017; Martela 2019; Martela \& Kostamo 2017), on mahdollista synnyttää psykologista turvallisuutta. Keinojen sen luomiseksi on kuitenkin oltava linjassa tiimin muun toiminnan kanssa.

\section{Jatkotutkimuksen aiheita}

Tutkimuksemme tulokset nostavat esille monia jatkotutkimusteemoja. Tutkimuksemme tarjoaa ääriesimerkin psykologisen turvallisuuden toteutumisesta ja se kohdistui erityislaatuiseen vapaaehtoisprojektiin, joka oli osa radikaalin itseilmaisun periaatteelle rakentuvaa Burning Man -taidefestivaalia. Jatkotutkimuksessa olisikin tärkeää arvioida tulostemme yleistettävyyttä. Mitkä tekijät ovat riippuvaisia projektin kontekstista tai pitäisi huomioida projektin lähtökohtia määriteltäessä, ja mitkä muodostuvat ryhmän toimiessa yhdessä? Tutkimuksella voitaisiin selvittää myös muutosprosesseja: mitkä tekijät ylläpitävät psykologista turvallisuutta, mikä voi tuhota koetun turvallisuuden tunteen, tai kuinka myrkyllinen työympäristö, jossa esiintyy kiusaamista, voidaan muuttaa sellaiseksi, jossa ryhmän jäsenet kokevat psykologista turvallisuutta. Lisäksi olisi mielenkiintoista selvittää tutkimuksen keinoin psykologisen turvallisuuden "periytyvyyttä". Kuinka samanlaisina esimerkiksi Suomen Burning Man -projektiryhmän toimintatavat ja psykologisen turvallisuuden kokemus säilyvät tulevina vuosina, kun projektiryhmän kokoonpano ja tavoitteet muuttuvat? Tutkimuksemme taustoittava mää- rällinen osio koostui vain 17 vastauksesta, joten tulevaisuudessa olisikin hedelmällistä tarkastella tämänkaltaista organisaatiota myös määrällisellä, tilastollisella tutkimusotteella ja kattavammalla vastaajamäärällä.

\section{Tulosten hyödyntäminen käytännössä}

Tutkimuksemme vastaa nykypäivän dynaamisen ja hyperkilpaillun työympäristön haasteisiin. Tiimin jäsenten tunteet ja yhteistoiminta ovat yhä tärkeämpiä, jotta organisaatiot voivat toimia luovasti. Organisaation oppimisesta ja muutoksensietokyvystä on tullut kriittinen menestystekijä. Työelämän yleisenä trendinä on, että organisaatioiden jäsenten odotetaan ottavan aiempaa aktiivisempaa roolia työssään. Tämä on herättänyt tutkijoiden mielenkiinnon tunnistaa tekijöitä, jotka edesauttavat työntekijöitä ottamaan riskejä ja investoimaan energiaa työhönsä (Kahn 1990).

Tuloksemme osoittavat, että psykologisen turvallisuuden synnyttämiseksi johtamiselta ei niinkään edellytetä tarkkoja sääntöjä tai epävarmuuden välttämistä. Sen sijaan, tuloksemme viittaavat siihen, että ihmiset kokevat osallisuutta hankkeesta, kun johtaminen on jaettua ja projektin jäsenet pääsevät osallistumaan tehtävien määrittelyyn, voivat valita tehtävänsä ja päättävät mitä hankkeella tavoitellaan. Luomalla vuorovaikutuskulttuuria, joka korostaa toisten arvostamista ja monipuolisuuden näkemistä rikkautena, luodaan edellytykset psykologisesti turvalliselle ja kannustavalle työnteolle, mikä on omiaan johtamaan myös parempiin tuloksiin modernissa asiantuntijatyössä. Tutkimuksemme kohteena oli itseohjautuva organisaatio, joka pohjautui vapaaehtoisuuteen. Tärkeää olisikin selvittää kuinka tässä tutkimuksessa tunnistettuja psykologista turvallisuutta vahvistavia tekijöitä voidaan toteuttaa tulosvastuullisissa tai hierarkkisemmissa organisaatioissa. Millä keinoin organisaatiomalleilla, johtamisella ja palkitsemisella voidaan vähentää pelkoja ja vastuun kasautumista, ja korostaa yhteisöllisyyttä? 


\section{LÄHTEET}

Aalto-yliopisto (2017). Finnish Design that conquered Burning Man can be even utilized in settlements in Mars. Haettu sivulta https:// www.aalto.fi/en/news/finnish-design-that-conquered-burning-man-can-be-utilised-even-inhuman-settlements-in-mars, 5.1.2020.

Bakker, René M. (2010). Taking stock of temporary organizational forms: A systematic review and research agenda. International Journal of Management Reviews, 12(4), 466-486.

Barsade, Sigal G. \& Gibson, Donald E. (2007). Why does affect matter in organizations? Academy of Management Perspectives, 21(1), 36-59.

Barsade, Sigal G. \& O'Neill, Olivia A. (2014). What's love got to do with it? A longitudinal study of the culture of companionate love and employee and client outcomes in a long-term care setting. Administrative Science Quarterly, 59(4), 551-598.

Bechky, Beth A. (2006). Gaffers, gofers, and grips: Role-based coordination in temporary organizations. Organization science, 17(1), 3-21.

Bennis, Warren G. (1965). Theory and method in applying behavioral science to planned organizational change. The Journal of Applied Behavioral Science, 1(4), 337-360.

Carmeli, Abraham \& Gittell, Jody Hoffer (2009). High-quality relationships, psychological safety, and learning from failures in work organizations. Journal of Organizational Behavior, 30, 709-729.

Chen, Katherine K. (2009). Enabling Creative Chaos: The Organisation behind the Burning Man event. Chicago: University of Chicago Press.

Christian, Michael S. \& Garza, Adela S. \& Slaughter, Jerel (2011). Work Engagement: A Quantitative Review and Test of Its Relations with Task and Contextual Performance Personnel Psychology 64(1), 89-136.

Duhigg, Charles (2016). What Google Learned from Its Quest to Build the Perfect Team. The New York Times Magazine. Haettu sivulta https://www.nytimes.com/2016/02/28/magazine/what-google-learned-from-its-quest-tobuild-the-perfect-team.html, 5.1.2020.

Edmondson, Amy C. (1999). Psychological safety and learning behavior in work teams. Administrative Science Quarterly, 44(2), 350-383.

Edmondson, Amy C. (2004). Psychological safety, trust, and learning in organizations: A group-level lens. Teoksessa Kramer, Roderick, M. \& Cook, Karen, S. (Eds.), Trust and distrust in organizations: Dilemmas and approaches (s. 239-272). New York: Russell Sage Foundation.

Edmondson, Amy C. \& Lei, Zhike (2014). Psychological safety: The history, renaissance, and future of an interpersonal construct. Annual Review of Organizational Psychology and Organizational Behavior, 1(1), 23-43.

Frazier, M. Lance, Fainshmidt, Stav, Klinger, Ryan L., Pezeshkan, Amir \& Vracheva, Veselina (2017). Psychological safety: A meta-analytic review and extension. Personnel Psychology, 70(1), 113-165.

Goodman, Richard Alan \& Goodman, Lawrence Peter (1976). Some management issues in temporary systems: A study of professional development and manpower-the theater case. Administrative science quarterly, 21(3), 494-501.

Grabher, Gernot (2002). Cool projects, boring institutions: temporary collaboration in social context. Regional studies, 36(3), 205-214.

Hakanen, Jari J., Perhoniemi, Riku \& ToppinenTanner, Salla (2008). Positive gain spirals at work: From job resources to work engagement, personal initiative and work-unit innovativeness. Journal of Vocational Behavior, 73(1), 78-91.

Jalonen, Harri, Lindell, Juha, Puustinen, Alisa \& Raisio, Harri (2013). Yhteistyön kääntöpuoli - kun itseorganisoituminen epäonnistuu ja ilmaantuminen yllättää. Hallinnon tutkimus, 32(4), 284-300.

Jones, Candace \& Lichtenstein, Benyamin B. (2008). Temporary inter-organizational projects. Teoksessa Cropper, Steve, Huxham, Chris, Ebers, Mark \& Smith Ring, Peter (Eds.), The Oxford handbook of inter-organizational relations (s. 231-255). Oxford: Oxford University Press.

Kahn, William A. (1990). Psychological conditions of personal engagement and disengagement at work. Academy of management journal, 33(4), 692-724.

Lee, Michael Y. \& Edmondson, Amy C. (2017). Self-managing organizations: Exploring the limits of less-hierarchical organizing. Research in Organizational Behavior, 37, 35-58.

Lundin, Rolf A. \& Söderholm, Anders (1995). A theory of the temporary organization. Scandinavian Journal of management, 11(4), 437-455.

Martela, Frank (2015). Fallible inquiry with ethical ends-in-view: A pragmatist philosophy of sci- 
ence for organizational research. Organization Studies, 36(4), 537-563.

Martela, Frank (2019). What makes self-managing organizations novel? - Comparing how Weberian bureaucracy, Mintzberg's adhocra$\mathrm{cy}$, and self-organizing solve six fundamental problems of organizing. Journal of Organization Design, 8(23). https://doi.org/10.1186/s41469019-0062-9

Martela, Frank \& Kostamo, Tuukka (2017). Adaptive self-organizing: The necessity of intrinsic motivation and self-determination. Teoksessa Eskola, Anne (Ed.), Navigating through changing times - Knowledge work in complex environments (4. luku). New York: Routledge.

Meyerson, Debra, Weick, Karl E. \& Kramer, Roderick M. (1996). Swift trust and temporary groups. Teoksessa Kramer, Roderick M. \& Tyler, Tom. R. (Eds.), Trust in Organizations: Frontiers of Theory and Research (s. 166-195), Thousand Oaks: Sage.

Saari, Tiina (2016). Resilienssi työntekijän voimavarana asiantuntijatyön aikapaineiden hallinnassa. Hallinnon tutkimus, 3, 232-243.

Saunders, Carol Stoak \& Ahuja, Manju K. (2006). Are all distributed teams the same? Differentiating between temporary and ongoing distributed teams. Small Group Research, 37(6), 662-700.
Schaufeli, Wilmar B., Shimazu, Akihito, Hakanen, Jari, Salanova, Marisa \& De Witte, Hans (2019). An Ultra-Short Measure for Work Engagement: The UWES-3 validation across five countries. European Journal of Psychological Assessment, 35(4), 577-591.

Spreitzer, Gretchen M. (1995). Psychological Empowerment in the Workplace: Dimensions, Measurement, and Validation. Academy of Management Journal, 38(5), 1442-1465.

Ståhle, Pirjo (2004). Itseuudistumisen dynamiikka. Systeemiajattelu kehitysprosessien ymmärtämisen tukena. Teoksessa Sotarauta, Markku \& Kosonen, Kati-Jasmin (toim.), Yksilö, kulttuuri, innovaatioympäristö. Avauksia aluekehityksen näkymättömään dynamiikkaan (s. 222-255). Tampere: Tampere University Press.

Team Learning and Psychological Safety Survey, Measurement Instrument Database for the Social Sciences (MIDSS). Haettu sivulta http://www. midss.org/content/team-learning-and-psychological-safety-survey, 5.1.2020.

Turner, Fred (2009). Burning Man at Google: a cultural infrastructure for new media production. New Media \& Society, 11(1-2) 73-94

Wageman, Ruth (1997). Critical success factors for creating superb self-managing teams. Organizational Dynamics, 26(1), 49-61.

Yin, Robert K. (2009). Case Study Research: Design and Methods (4th ed.). Thousand Oaks: Sage. 